\title{
COURT AWARDED ATTORNEYS' FEES IN RECOGNITION OF STUDENT LAWYERING
}

Programs of clinical instruction are increasingly regarded as an important supplement to traditional legal education. ${ }^{1}$ The clinical movement emerged from two independent sources: a recognition that the clinical setting may be better suited than the classroom to fostering practical skills and developing professional responsibility, ${ }^{2}$. and an increased awareness of the need to improve the delivery of legal services to all sectors of society. ${ }^{3}$ Unlike their counterparts in the classroom, law students in clinical programs render legal services to real clients with real legal problems. ${ }^{4}$ The students thereby gain valuable practical experience and provide legal assistance to persons whose needs otherwise would remain unmet.

The concern for broader availability of legal services has caused changes in the structure of the legal system as well. An example of such change is the proliferation of statutory provisions allowing

1 See, e.g., Burger, The Future of Legal Education, in Councu on LEGAL Education for Professional Responstbulty \& International Legal Center, Selected Readings in Clinical Legal Education 49 (1973) (advocating increased clinical education); Rubin, The View From the Bench, in CouncI on Legar Education for Professtonal Responsibitity, Inc., Cutnical Education for the Law Student: Legal Education in a Service Serting 251 (1973) (working papers prepared for CLEPR National Conference in Buck Hill Falls, Pennsylvania, June $6-9,1973)$. For articles and comments discussing the purpose and importance of clinical legal education, see generally F. KrEIN, S. LELEIKo \&.J. MAVITY, BAR Admisston Rules and Student Practice Ruzes, 983-88 (1978) [hereinafter cited as F. KrerN] (bibliography); Barnhizer, The Clinical Method of Legal Instruction: Its Theory and Implementation, $30 \mathrm{~J}$. LEGAL EDuc. 67, 68 (1979); Gee \& Jackson, Bridging the Gap: Legal Education and Lawyer Competency, 1977 B.Y.U. L. REv. 695, 881-92; Snyman, A Proposal for a National Link-up of The New Legal Services Corporation Law Offices and Law School Clinical Training Programs, 30 J. Lecal Enuc. 43, 56-66 (1979) (bibliography).

2 Association of American Law Schools-American Bar Assoctatron Coapaittee on Gumelines for Clinical legal Education, Guidelines for Cinical Legal Educatron 7-8 (1980) [hereinafter cited as Guideinnes]. Seb Vetri, On Teaching Professional Responsibility Through Clinical Legal Education Programs, in Council on Legal Education for Professional Responsibitity, Inc., Clinical EdUCATION FOR THE LAW STUDENT 70 (1973) (proceedings of CLEPR conference in Buck Hill Falls, June 1973) [hereinafter cited as Buck Hill Falls Proceedings]. Recent proposals have recommended instruction in trial advocacy as a requirement for admission to practice before federal courts. See GondenINEs, supra, at 8 \& n.12.

3 GuDDE.INES, supra note 2, at 7-8. Justice Brennan has described clinical programs as an important source of legal representation for the indigent. See Argersinger v. Hamlin, 407 U.S. 25, 40-41 (1972) (Brennan, J., concurring).

4 See infra text accompanying notes 15-37. For interesting descriptions of clinical programs, see Meltsner \& Schrag, Scenes From a Clinic, 127 U. PA. L. REv. 1 (1978) (Columbia University's Morningside Heights Legal Services Corporation); Subin, Directing and Managing Legal Education in a Service Setting, in Buck Hill Falls Proceedings, supra note 2, at 57, 64 (New York University's Criminal Law Clinic). 
courts to award attorneys' fees to litigants who successfully vindicace their rights under certain statutory schemes. ${ }^{5}$ These provisions, along with equitable doctrines allowing courts to award fees, have increased the availability of legal services for the indigent by providing incentives for such persons to seek, and for attorneys to provide, legal representation on a cost-free basis. ${ }^{6}$

This Comment discusses the appropriateness of awarding attorneys' fees to law school legal clinics in recognition of the lawyering services of students enrolled in them. The analysis is limited to law school legal clinics in which students, by virtue of special authorization, ${ }^{7}$ are allowed to provide indigent clients with legal services that otherwise could be performed only by licensed attorneys. ${ }^{8}$

The issue is a novel one. Although courts occasionally have awarded attorneys' fees to university-affiliated legal assistance offices based on the supervising attorney's work, ${ }^{9}$ and in some instances

- The most far-reaching provision is The Civil Rights Attorney's Fees Awards Act of 1976, Pub. L. No. 94-599, 90 Stat. 2641 (codified at 42 U.S.C. $\$ 1988$ (1976)). Its sponsor in the Senate, Senator Tunney, explained:

In the typical case ... the citizen whose rights have been violated has little or no money with which to hire a lawyer, and there is often no damage claim from which an attorney could draw his fee. If private citizens are to be able to assert their rights under these laws-if those who violate these most basic human freedoms are not to proceed with impunity-then citizens must have the opportunity to recover what it costs them to vindicate these rights in court.

121 Cong. Rec. 26,806 (1975). For a list of the more than 100 other federal provisions authorizing attorneys' fees awards, see Award of Attorneys' Fees Against the Federal Government: Hearings on S. 265 Before the Subcomm. on Coutts, Civil Liberties, and the Administration of Justice of the House Comm. on the Judiciary, 96th Cong., 2d Sess. 611-29 (1980) [hereinafter cited as Hearings on S. 265].

'For a discussion of the effect of attorneys' fees on the availability of legal representation, see The Effect of Legal Fees on the Adequacy of Representation: Hearings Before the Subcomm. on Representation of Citizen Interests of the Senate Comm. on the Judiciary, 93d Cong., 1st Sess. (1973).

7 See infra note 21 and accompanying text.

8 The analysis is limited for several reasons. First, only when students actually perform lawyering services for clients may attorneys' fees in direct recognition of their efforts properly be considered. Some jurisdictions permit students to render such services only in law school legal services offices. See, e.g., D.C. CrR. R. 20; D. HAWAII R. 1(1); F. KLEIN, supra note 1, at 960-77. Second, some jurisdictions limit the scope of representation to indigent clients. See, e.g., 3D CR. R. 9(3); D.N.H. R. 5(c); F. KLEIN, supra note 1, at 960-77. Although the clinic's organization 'or its clients' financial status may not be crucial to a resolution of the issue, the restrictive definition used here may produce a more generally applicable analysis: it avoids those variables, such as a broader scope of representation which might include nonindigent clients, that will not apply to all clinical settings.

${ }^{9}$ Loney v. 'Scurr, 494 F. Supp. 928 (S.D. Iowa 1980); Mercharidise Nat'I Bank v. Scanlon, 86 Ill. App. 3d 719, 408 N.E.2d 248 (1980); Darmetko v. Boston Hous. Auth., 79 Mass. Adv. Sh. 2159, 393 N.E.2d 395 (1979). 
have increased the amount of these awards in recognition of law students' efforts, ${ }^{10}$ no court has recognized a student as the "attorney" for the purpose of awarding attorneys' fees.

Including the lawyering services of students in computing fee awards could permit law school clinics to assume a larger role in the advancement of important public policies by encouraging litigants to vindicate their rights. Fee awards also. could provide universities with funding to support clinical education. ${ }^{11}$ As clinical programs expand, both in number ${ }^{12}$ and in the range of clients and matters they serve, ${ }^{13}$ and as statutes allowing attorneys' fees proliferate, ${ }^{14}$ the issue will become increasingly important.

Part I of this Comment briefly describes law school clinical programs and the student's role within them. Part II discusses some of the doctrines and statutory provisions allowing fee awards,

10 Darmetko v. Boston Hous. Auth., 79 Mass. Adv. Sh. 2159, 393 N.E.2d 395 (1979). But see Loney v. Scurr, 494 F. Supp. 928 (S.D. Iowa 1980); of. CTS Corp. v. Electro Materials Corp., 476 F. Supp. 144 (S.D.N.Y. 1979) (denying fees to compensate for law student services rendered to corporation counsel).

11 The importance of this potential source of funding cannot be overstated. Clinical education is expensive; schools may be tempted to curtail it in times of financial stress. See generally Councri on Legar Education for Professional Responsibitrty, Inc., Survey and Drrectory of Cunnical Legal Education 1978-1979 xxvii (1979); deL Swords \& Walwer, Cost Aspects of Clinical Education, in GUDELINES, supra note 2, at 133.

12 See Councti on Legai Education for Professionat Responsibitity, Inc., Survex and Directory of Clinical Legar Education 1976-1977 iv-viii (1977).

13 See Gumer.INEs, supra note 2, at 88 (encouraging removal of restrictions, such as indigency requirements, on the scope of representation and noting that by 1979 the ABA model student practice rule, as well as nine state and thirteen federal student practice rules, authorized student representation regardless of clients' indigency).

14 Increasingly, Congress has incorporated fee awards provisions as essential elements in statutory schemes. See supra note 5. Congress also has expanded the authority of federal courts and agencies to award attorneys' fees in proceedings to which the United States is a party. The Equal Access to Justice Act, Pub. L. No. 96-481, $\$ 201-208$; 94 Stat. 2321, 2325 (1980) (to be codified in scattered sections of 5, 26, 28, 41 U.S.C.), authorizes fee ${ }^{x}$ awards to parties who prevail in agency adjudications and provides for awards against the United States in civil actions. Other measures that have been considered in recent years include bills that in some circumstances would award fees to public participants in -agency rulemaking and would provide for fee reimbursement to citizens seeking review of agency actions in federal court. See, e.g., S. 270, 95th Cong., 1st Sess.; H.R. 3361, 95th Cong., 1st Sess.; S. 262, 86th Cong., 1st Sess.; H.R. 3263, 96th Cong., Ist Sess.; H.R. Rep. No. 1393, 96th Cong., 2d Sess. (1980). For discussion and evaluation of these and similar measures, see Regulation Reform Act of 1979: Hearings Before the Subcomm. on Administrative Law and Governmental Relations of the House Comm. on the Judiciary, 96th Cong., Ist \& 2d Sess. (1979-1980); Regulatory Reform: Hearings Before the Subcomm. on Administrative Practice and Procedure of the Senate Comm. on the Judiciary, 96th Cong., 1st Sess., pt. 2 (1979); The Awarding of Attorneys' Fees in Federal Courts: Hearings Before the Subcomm. on Courts, Civil Liberties, and the Administration of Justice of the House Comm. on the Judiciary, 95th Cong., 1st \& 2d Sess. (1977-1978). 
paying particular attention to the policies underlying them to demonstrate that fee awards recognizing student services will help to implement those policies. Part III examines cases in which attorneys' fees awards have been sought for the services of someone other than a licensed attorney to determine whether fee awards based on student services are consistent with these decisions. Part IV concludes that attorneys' fees in recognition of student lawyering should be awarded.

\section{The Law Student's Role in the Law School Legal Glinic}

The general objectives of clinical education may be furthered through student participation in a number of different activities. ${ }^{15}$ Interviewing, fieldwork, legal and factual analysis, and drafting and reviewing documents all permit the student to gain the practical experience that the classroom cannot provide. The most significant elements of participation in clinical courses, however, are the opportunities for the student to counsel his or her clients, ${ }^{10}$ to negotiate on their behalf, 17 and to represent them in formal legal proceedings. ${ }^{18}$ In so doing, the student most fully acts as an attorney, performing tasks not readily equated with the work undertaken by clerks or paralegals.

Each jurisdiction must authorize student participation in these activities. ${ }^{18}$ Qualified students generally must be certified, usually by the court clerk on the recommendation of the law school's Dean. ${ }^{20}$ Malpractice insurance sometimes must be carried to cover the student, ${ }^{21}$ and he or she may be required to be familiar with

15 See GUIDELINES, supra note 2, at 12-14.

16 Some federal and state courts specifically allow certified students to counsel their clients. See, e.g., D. HawaII R. I(1)(5); F. KuEIN, supra note 1, at 917, 924,946 n.36, 950 n.87. See also E.D. PA. R. I2F (authorizing students to "engage in all activities on behalf of [their] client [s] that a licensed attorney may engage in").

17 Some courts permit students to negotiate for their clients. See, e.g., D. HAWATI R. I(1) (5); F. KI.FIN, supra note 1 , at $918,924,946$ n.41, 950 n.86.

${ }^{18}$ See infra note 24 and accompanying text. In addition to allowing court appearances, many states have allowed students to appear before other tribunals, such as administrative agencies. See F. KLEIN, supra note 1, at 916.

19 Authorization may be by statute, see, e.g., GA. CODE ANN. $\$ \$ 9-401.1$ to .2 (1973 \& Supp. 1981), or by court rule, see, e.g., E.D. PA. R. 12 . Without such authorization, student representation of clients would constitute the unauthorized practice of law. See generally Fra. Stat. ANN. \$454.23 (West 1981); N.Y. Jum. LAw $\$ 478$ (McKinney Supp. 1980) (statutes prohibiting the unauthorized practice of law).

20 See, e.g., GA. CODE ANN. \$9-401.1(i) (1973); ABA MOdeL STudent PrActice RuLE $\$ \oint$ III, IV, reprinted in F. KuEIN, supra note 1, at 993, 994.

21 See, e.g., GA. CoDE ANN. $\$ 9-401.1$ (g) (1973); F. Kretn, supra note 1, at 919, 947 n.48. The GuIDELINEs, supra note 2, at 91-92, recommend that all clinical programs carry malpractice insurance for students. 
the Code of Professional Responsibility. ${ }^{22}$ Some states have brought certified students within the scope of the attorney-client privilege.23

Court appearances are liberally sanctioned. At least forty-four states, the District of Columbia, and Puerto Rico have allowed certified students to appear in court. ${ }^{24}$ On the federal level, twentyfour district courts and four courts of appeals ${ }^{25}$ have followed the recommendation of the Judicial Conference of the United States and provided for student practice. $^{26}$ Appellate work, including oral argument, often is permitted. ${ }^{27}$

The degree of supervision required over these students varies with the jurisdiction and the matter at issue. For example, the American Bar Association Model Student Practice Rule, ${ }^{28}$ upon which some states have patterned their rules, allows unsupervised student appearances on behalf of indigent clients in any civil matter ${ }^{29}$ or in any criminal matter in which the defendant does not have a right to counsel, ${ }^{30}$ provided that the client has consented. Maryland requires personal supervision of all courtroom appearances by students, ${ }^{31}$ whereas Massachusetts ${ }^{32}$ and New Hampshire ${ }^{33}$ have provided that a supervising attorney need offer only general supervision, which does not require physical presence in court.

These provisions illustrate the varying circumstances in which a law student is allowed to function as an attorney in order to render a variety of legal services to his or her client; they raise the question whether courts should recognize students' services for the purpose of awarding attorneys' fees.

22 At least twenty-one states have required students to read the Code of Professional Responsibility. F. Krune, supra note 1, at 921,948 n.59. Four of these and six additional states have required students to take oaths affirming their familiarity with the Code. Id. 922,949 n.65. See also Gundendes, supra note 2, at 27 ("[a] student participating in a client clinic assumes responsibility to act in accordance with the applicable code of professional responsibility"). 918-19.

${ }^{23}$ Arizona, Ohio, and Texas have done so. See F. Kr.EIN, supra note 1, at

24 See the list compiled in F. KI.En, stupra note 1, at 960-69.

25 Id. 972-81.

26 AdMinistrative OfFice of the UNIted States Courts, Reports of the Proceiedngs of the Judiclal Conference of the Untted States 80-81 (1971). 27 See, e.g., 3D CIr. R. 9(3); 4TH CR. R. 13; D.C. Crr. R. 20.

28 ABA Model Student Practice Rule, reprinted in F. Krein, supta note 1 , at $993-95$.

20 ABA Model Student Practice RuLe $\$ I I(A)(1)$, reprinted in F. Kretr, supra note 1 , at 993,994 .

30 Id. $\$ \operatorname{II}(\mathrm{A})(2)$.

31 Md. Rules for Bar Adarssion Code ANis. Rule 18(d) (1981).

32 F. KLEIN, supra note 1 , at 1064-65.

33 Id. 1084. 


\section{Bases for Court Awarded Attorneys' Fees}

As a general rule, a successful litigant in American courts bears the costs of his or her legal representation. ${ }^{34}$ A number of exceptions to this principle, however, have been created either through the equitable powers of the courts or by statute. This section describes in general terms those exceptions and the policies. underlying them, with particular attention to the exceptions that are relevant to a law school legal clinic.

\section{A. Equitable Doctrines}

Notwithstanding the general rule against recovery of attorneys' fees from losing opponents, the federal courts have long recognized their inherent power to order such recovery "when the interests of justice so require." ${ }^{35}$ In Alyeska Pipeline Service Co. v. Wilderness Society, ${ }^{36}$ the Supreme Court identified three distinct equitable rationales courts have used for this purpose: the bad faith exception, the common benefit theory, and the private attorney general doctrine.

The bad faith rationale allows a court, in the exercise of its equity powers, to award attorneys' fees to a party whose "opponent has acted in bad faith, vexatiously, wantonly, or for oppressive reasons ...." ${ }^{37}$ The doctrine applies to two types of conduct: that which induces litigation and that which occurs during litigation.

34 The rule was first articulated in 1796 in Arcambel v. Wiseman, 3 U.S. (3 Dall.) 306 (1796), and has been followed since that time. See Alyeska Pipeline Serv. Co. v. Wilderness Soc'y, 421 U.S. 240, 249-50 (1975). The rule is generally supported on two grounds: that it would be unfair to penalize an honest litigant for bringing a claim or offering a defense, and that to hold a party liable for the victor's legal fees would deter the poor from vindicating their rights in court. Fleischmann Distilling Corp. v. Maier Brewing Co., 386 U.S. 714, 718 (1967).

The American rule has met with substantial criticism. Opponents have accused the rule of failing to serve its objectives and have advocated replacing it with a general rule awarding attorneys' fees to the prevailing party. See, e.g., Ehrenzweig, Reimbursement of Counsel Fees and the Great Society, 54 CALIF. L. Rev. 792 (1966); Kuenzel, The Attorney's Fee: Why Not a Cost of Litigation?, 49 Iowa L. Rev. 75 (1963); McCormick, Counsel Fees and Other Expenses of Litigation as an Element of Damages, 15 MiNN. L. Rev. 619 (1931); McLaughlin, The Recovery of Attorney's Fees: A New Method of Financing Legal Services, 40 Fondriar L. Rev. 761 (1972); Stoebuck, Counsel Fees Included in Costs: A Logical Development, 38 U. CoLo. L. REv. 202 (1966).

${ }^{35}$ Hall v. Cole, 412 U.S. 1, 5 (1972). The Court declared that this power is derived from "the original authority of the chancellor to do equity in a particular situation.” Id. (quoting Sprague v. Ticonic Nat'l Bank, 307 U.S. 161, 166 (1939)). 86421 U.S. 240 (1974).

${ }^{37}$ F.D. Rich Co. v. United States ex rel. Industrial Lumber Co., 417 U.S. 116, 129 (1974). See generally 6 J. MoORE, W. TAGgart \& J. WickER, Moore's FEDerat Practice f 54.77(2) (2d ed. 1976). 
The first occurs when a party blatantly refuses to respect another's legal rights, thereby forcing that person to sue to enforce those rights. ${ }^{38}$ The second occurs during the litigation when either party engages in unnecessarily obnoxious conduct, such as filing groundless motions, impeding discovery, failing to stipulate to matters not genuinely at issue, or otherwise displaying general obstinancy. ${ }^{38}$

An award of fees in either situation serves two purposes. It reimburses the injured party for the unnecessary litigation expenses; ${ }^{10}$ by punishing the wrongful conduct, it seeks to deter similar conduct in the future. ${ }^{41}$ This rationale for fee awards, therefore, reflects considerations broader than the particular financial relationship between attorney and client.

The common benefit exception, which is founded on principles of unjust enrichment, ${ }^{42}$ allows a court to award fees to a successful

38 See, e.g., Vaughan v. Atkinson, 369 U.S. 527, 530-31 (1962); Richardson v. Communications Workers, 530 F.2d 126, 131-32 (8th Cir.), cert. denied, 429 U.S. 824 (1976); Doe v. Poelker, 515 F.2d 541, 546-48 (8th Cir. 1975), rev'd on other grounds, 432 U.S. 519 (1977); McEnteggart v. Cataldo, 451 F.2d 1109, 1112 (1st Cir. 1971); Bell v. School Bd., 321 F.2d 494, 500 (4th Cir. 1963); Rolax v. Atlantic Coast Line R.R. Co., 186 F.2d 473, 481 (4th Cir. 1951); Guardian Trust Co. v. Kansas City Southern Ry., 28 F.2d 233, 240 (8th Cir. 1928); Miller v. Carson, 401 F. Supp. 835, 853-57 (M.D. Fla. 1975), affd in part, modified in part and remanded on different grounds, 563 F.2d 741 (5th Cir. 1977); Sims v. Amos, 340 F. Supp. 691, 693-84 (M.D. Ala. 1972), affd, 409 U.S. 942 (1972).

${ }^{39}$ See, e.g., Browning Debenture Holders' Comm. v. DASA Corp., 560 F.2d 1078, 1087-89 (2d Cir. 1977); Fairley v. Patterson, 493 F.2d 598, 608 (5th Cir. 1974); Red School House, Inc. v. Office of Economic Opportunity, 386 F. Supp. 1177, 1196-98 (D. Minn. 1974); Gates v. Collier, 371 F. Supp. 1368, 1371 (N.D. Miss. 1973), vacated and remanded, 522 F.2d 81 (5th Cir. 1975), opinion on remand, 70 F.R.D. 341 (N.D. Miss. 1976); aff'd in part, rev'd in part, and temanded, 559 F.2d 241 (5th Cir. 1977).

Bad faith conduct during discovery can lead to an award of attorneys' fees. See FED. R. Crv. P. 37(c) (allowing a party to request payment of expenses, including attorneys' fees, incurred in proving genuineness or truth, when his opponent in a Rule 36 request for discovery denies the genuineness of a document or the truth of a matter of fact). For a discussion of the complexities of judicial determinations under the bad faith rule, see Comment, Nemeroff v. Abelson, Bad Faith, and Awards of Attorneys' Fees, 128 U. PA. L. REv. 468 (1979).

40 Vaughan v. Atkinson, 369 U.S. 527, 531 (1962) ("As a result of that recalcitrance, libellant was forced to hire a lawyer and go to court to get what was plainly owed him"); Fairley v. Patterson, 493 F.2d 598, 606 (5th Cir. 1974).

11 See Hall v. Cole, 412 U.S. 1, 5 (1973); Copeland v. Martinez, 603 F.2d 981, 991-92 (D.C. Cir. 1979), cert. denied, 444 U.S. 1044 (1980). Some state rules establish a bad faith standard similar to that of the federal rule. See, e.g., GA. CoDe ANN. \$20-1404 (1977); Inr. ANN. STax. ch. 110, \$ 41 (Smith-Hurd Supp. 1981); N.D. Cent. Code \$28-26-31 (1974). Other states allow attorneys' fees awards at the general discretion of the court. See, e.g., Or. REv. STAT. $\$ 20.010$ (1979). See generally Comment, Attorney's Fees and the Federal Bad Faith Exception, 29 Hastangs L.J. 319 (1977).

12 Dawson, Lawyers and Involuntary Clients in Public Interest Litigation, 88 Harv. L. Rev. 849, 850 (1975). See Restatement of Restitution $\$ 1$ (1937). 
party whose suit results in the enrichment of others as well. Fees then may be recovered from that benefited class. ${ }^{43}$ The common benefit exception applies only when "a litigant confers a substantial benefit on an easily identifiable class . . . where the benefit can be traced with reasonable accuracy, and the costs of litigation can be shifted with some exactitude, to those benefiting." 44 The doctrine originated in cases in which the suit created a common fund that a specific group could use; ${ }^{45}$ it was later expanded to include cases producing a benefit, but no specific pool of funds.46 Most recently, the exception has been applied to suits under the Landrum-Griffin Act: ${ }^{47}$ successful suits by specific union members are considered to benefit all members of the union..$^{48}$

Before Alyeska, the courts used the private attorney general doctrine to justify awards of attorneys' fees to litigants who had created benefits, not for a discrete group, but for the public at large. ${ }^{49}$ These litigants were seen as "private attorneys general" who through their own effort furthered important public interests. ${ }^{50}$ The Alyeska Court disapproved of this doctrine, not because its underlying reasoning was unsound, but because the courts are without authority to judge some statutes more important than

43 See Trustees v. Greenough, 105 U.S. 527, 532 (1882) ("He has worked for them as well as for himself ... they ought to contribute their due proportion of the expenses which he has fairly incurred."). See generally Hornstein, Legal Therapeutics: The "Salvage" Factor in Counsel Fee Awards, 69 HARv. L. REv. 658, 662-63 (1956); Note, The Allocation of Attorney's Fees After Mills v. Electric Auto-Lite Co., 38 U. Crm. L. REv. 316, 328-36 (1971).

44 Stevens v. Municipal Court, 603 F.2d 111, 112 (9th Cir. 1979).

45 See Sprague v. Ticonic Nat'l Bank, 307 U.S. 161 (1939); Trustees v. Greenough, 105 U.S. 527 (1882).

46 See generally Hall v. Cole, 412 U.S. 1, 7 (1973); Mills v. Electric Auto-Lite Co., 396 U.S. 375, 392 (1970). For an exhaustive treatment of this doctrine and criticism of its inappropriate application, see Dawson, Lawyers and Involuntary Clients: Attorney Fees from Funds, 87 HaRv. L. REv. 1597 (1974).

47 Labor-Management Reporting and Disclosure Act of 1959, Pub. L. No. 86-257, 73 Stat. 519 (codified at 29 U.S.C. $\$ \$ 401-531$ (1976)).

48 See, e.g., Rosario v. Amalgamated Ladies' Garment Cutters' Union, Local 10, 605 F.2d 1228 (2d Cir. 1979), cert. denied, 446 U.S. 919 (1980); Brennan v. United Steelworkers, 554 F.2d 586 (3d Cir. 1972), cert. denied, 435 U.S. 977 (1978); McDonald v. Oliver, 525 F.2d 1217 (5th Cir.), cert. denied, 429 U.S. 817 (1976); Yablonski v. United Mine Workers, 466 F.2d 424 (D.C. Cir.), cert. denied, 421 U.S. 918 (1972); Hummel v. Brennan, 469 F. Supp. 1180 (E.D. Pa. 1979).

19 The public, however, does not pay the plaintiff's attorneys' fees; the defendant does. For general discussion of the doctrine, see Note, Awarding Attorneys ${ }^{3}$ Fees to the "Private Attorney General": Judicial Green Light to Private Litigation in the Public Interest, 24 Hastancs L.J. 733 (1973); Comment, Court Awarded Attorney's Fees and Equal Access to the Courts, 122 U. PA. L. REv, 636, 655-81 (1974).

60 The doctrine was formulated in Newman v. Piggie Park Enterprises, Inc., 390 U.S. 400,402 (1968). 
others, and to allocate attorneys' fees accordingly, without legislative guidance. ${ }^{51}$

\section{B. Statutory Provisions: The Civil Rights Attorney's Fees Awards Act}

No fewer than one hundred federal statutes ${ }^{52}$ contain provisions allowing or requiring courts to award attorneys' fees to parties who prevail in proceedings brought under them. Underlying many of these provisions are the notions that private enforcement is essential to the promotion of the substantive statutory scheme and that the potential award of attorneys' fees encourages private enforcement. ${ }^{\text {.3 }}$

The statute most significant to law school clinics was enacted in direct response to Alyeska: the Civil Rights Attorney's Fees Awards Act (Fees Act). ${ }^{54}$ Congress found that the Court's decision in Alyeska had created "anomalous gaps" in the policies underlying the civil rights laws. ${ }^{55}$ The Fees Act, therefore, allows litigants prevailing on claims under certain enumerated statutes ${ }^{66}$ to collect attorneys' fees from the losing party.

The Fees Act serves the basic goal of the civil rights lawsdiscouraging violations of individuals' civil rights-in two re-

51 Alyeska, 421 U.S. at 263-64. The private attorney general doctrine may still be applicable in the state courts. See, e.g., Serrano v. Priest, 20 Cal. $3 \mathrm{~d} 25$, 569 P.2d 1303, 141 Cal. Rptr. 315 (1977).

62 For a list of these provisions, see Hearings on S. 265, supra note 5, at 611-29.

53 See, e.g., H.R. REP. No. 499, 94th Cong., 1st Sess. (1976), reprinted in 1976 U.S. CODE CONG. \& AD. NEws 2572 (Hart-Scott-Rodino Antitrust Improvements Act); S. ReP. No. 854, 93d Cong., 2d Sess. 17-20 (1974) (Freedom of Information Act Amendments); S. REP. No. 1183, 93d Cong., 2d Sess. (1974), reprinted in 1974 U.S. Code Cong. \& AD. News 6916 (Privacy Act Amendments).

54 Civil Rights Attorney's Fees Awards Act of 1976, Pub. L. No. 94-559, 90 Stat. 2641 (Fees Act) (codified at 42 U.S.C. $\$ 1988$ (1976)). For congressional discussion of Alyeska, see 121 Cong. Rec. 26,806 (1975); S. Rep. No. 1011, 94th Cong., $2 \mathrm{~d}$ Sess. 1 (1976), reprinted in 1976 U.S. CoDe CoNg. \& Ad. NEws 5908, 5909; H.R. REp. No. 1558, 94th Cong., 2d Sess. 2.

55 S. REP. No. 1011, 94th Cong., $2 d$ Sess. 1 (1976), reprinted in 1976 U.S. Code Cong. \& AD. News 5908, 5909.

56 The statutory provisions covered by the Fees Act include 42 U.S.C. $\$ 1981$ (1976) (equal rights under the law to all persons); 42 U.S.C. $\$ 1982$ (1976) (equal property rights); 42 U.S.C. $\$ 1983$ (Supp. III 1979) (liability for depriving a citizen of rights under color of state law); 42 U.S.C. \$1985 (Supp. III 1979) (conspiracies to abridge civil rights); 42 U.S.C. $\$ 1986$ (1976) (liability for failure to prevent violations of $\$ 1985$ ); Title IX of the Education Amendments of 1972, Pub. L. No. 92-318, $\$ \$ 901-907,86$ Stat. 235,373 (codified at 20 U.S.C. $\$ \S 1681-$ 1686 (1976)) (discrimination in educational programs); Title VI of the Civil Rights Act of 1964, Pub. L. No. 88-352, $\$ \$ 601-605,78$ Stat. 241, 252 (codified at 42 U.S.C. $\$ 2000 \mathrm{~d}$ to $2000 \mathrm{~d}-6$ (1976 \& Supp. III 1979)) (racial discrimination in federally assisted programs). 
spects: ${ }^{57}$ it helps to open the courtroom to citizens with valid claims, despite their financial constraints, and it forces violators of basic civil rights to bear the burden of their actions. ${ }^{58}$

The Fees Act makes an award of attorneys' fees a matter of discretion for the court. ${ }^{59}$ Congress intended that prevailing plaintiffs under the Fees Act "should ordinarily recover an attorney's fee unless special circumstances would render such an award unjust." ${ }^{\circ}$ Consistent delineation of such special circumstances has proved to be a difficult task for the courts. In essence, however, a finding of special circumstances represents a judgment about a case's particular facts. $^{\text {}}{ }^{2}$ Such findings have not been commonly used to deny attorneys' fees because of the financial structure of the attorney-client relationship. ${ }^{62}$

57 See supra note 5.

58 See S. ReP. No. 1011, 94th Cong., 2d Sess. 2 (1976), reprinted in 1976 U.S. Code Cong. \& AD. News 5908, 5909; H.R. Rep. No. 1558, 94th Cong., 2 d Sess. 1 (1976). For the legislative history of the Fees Act, see Subcommrtre on Constitutional Rughts of the Senate Comantree on the Judiciary, 94th Cong., 2D Sess., Civil. Rights Atrorney's Fees Awards Act of 1976 Source Boox (Comm. Print 1976).

5942 U.S.C. $\$ 1988$ (1976).

60 S. ReP. No. 1011, 94th Cong., 2d Sess. 4 (1976), reprinted in 1976 U.S. CoDe Cong. \& AD. News 5908, 5912 (quoting Newman v. Piggie Park Enterprises, Inc., 390 U.S. 400, 402 (1968)).

61 Some courts have denied or reduced awards because of a noticeable lack of public benefit resulting from the suit. See, e.g., Martin v. Hancock, 466 F. Supp. 454 (D. Minn. 1979); Zarcone v. Perry, 438 F. Supp. 788 (E.D.N.Y. 1977), affd, 58I F.2d 1039 (2d Cir. 1978), cert. denied, 439 U.S. 1072 (1979); Naprstek v. City of Norwich, 433 F. Supp. 1369 (N.D.N.Y. 1977).

Courts also have denied or reduced awards when a large award would have impaired the defendant's ability to rectify the error. See, e.g., Keyes v. School Dist. No. 1, 439 F. Supp. 393, 414-15 (D. Colo. 1977); of. Oliver v. Kalamazoo Bd. of Educ., 576 F.2d 714 (6th Cir. 1978) (concurring opinion) (court may consider limited nature of public resources in determining attorneys' fees). But see McPherson v. School Dist. No. 186, 465 F. Supp. 749, 757 (S.D. Ml. 1978).

Finally, courts have denied or reduced attorneys' fees when the plaintiff's damages under the claim prevailed upon were either too large, e.g., Buxton v. Patel, 595 F.2d 1182, 1185 (9th Cir. 1979) ("adequate compensation to counsel was provided from the recovery"); Zarcone v. Perry, 581 F.2d 1039, 1044 (2d Cir. 1978), cert. denied, 439 U.S. 1072 (1979) (chances of receiving "substantial" award were sufficiently high to attract competent counsel on a contingency fee basis), or too small, e.g., Perez v. University of P.R., 600 F.2d I (Ist Cir. 1979) (attorney's fees may be reduced if award is nominal); Huntley v. Community School Bd. of Brooklyn, 579 F.2d 738 (2d Cir. 1978) ("moral victory" won was of "insufficient magnitude" to justify awarding attorney fees); Beazer v. New York City Transit Auth., 558 F.2d 97 (2d Cir. 1977), rev'd. on other grounds, 440 U.S. 568 (1979) (benefits to plaintiff class were not sufficiently concrete).

62 See, e.g., Puch v. Rainwater, 465 F. Supp. 41 (S.D. Fla. 1979); Regalado v. Johnson, 79 F.R.D. 447 (E.D. Ill. 1978); Mid-Hudson Legal Servs. v. G \& U, Inc., 465 F. Supp. 261 (S.D.N.Y. 1978); Aumiller v. University of Del., 455 F. Supp. 676 (D. Del. 1978), affd., 594 F.2d 854 (3d Cir. 1979); cf. Arkansas Community Orgs. v. Arkansas State Bd., 468 F. Supp. 1254 (E.D. Ark. 1979) ("organizational counsel" awarded fees even though he received a general salary 


\section{A Functional Concept of the Attorney}

A determination whether awards of attorneys' fees for student lawyering are consistent with precedent requires an examination of courts' interpretations of the word "attorneys" in attorneys" fees. A court could approach this problem in two ways. The first is formal and would conclude that attorneys' fees may be awarded only to licensed lawyers. The second is functional and would conclude that attorneys' fees may be awarded to recognize the performance of legal services even if they are not provided by licensed attorneys.

Two lines of decisions indicate that courts generally have taken a functional rather than a formal approach in defining "attorneys" in this context. In the first line of cases, courts have included in fee awards separate compensation for the services provided by the "legal" support staff: paralegals, student clerks, or summer associates. ${ }^{63}$

The functional concept of "attorney" justifies this treatment of legal support staff. Separate compensation is appropriate for nonlawyers if their work otherwise would have to be performed by an attorney. ${ }^{64}$ In fact, legal support services, like an attorney's

from plaintiffs). But see Gagne v. Maher, 594 F.2d 336 (2d Cir. 1979), affd. on other grounds, 448 U.S. 122 (1980); cf. McPherson v. School Dist. No. 186, 465 F. Supp. 749 (S.D. IIl. 1978) (attorney's fees reduced from time when payment by legal aid fund became certain; before this time, fee was contingent).

${ }^{63}$ See, e.g., Pacific Coast Agricultural Export Ass'n v. Sunkist Growers, Inc., 526 F.2d 1196, 1210 n.19 (9th Cir. 1975), cert. denied, 425 U.S. 959 (1976); Bolden v. Pennsylvania State Police, 491 F. Supp. 958, 964-65 (E.D. Pa. 1980); Wehr v. Burroughs Corp., 477 F. Supp. 1012, 1017 (E.D. Pa. 1979), modified, 619 F.2d 276 (3d Cir. 1980); Pennsylvania v. O'Neill, 431 F. Supp. 700, 711 (E.D. Pa. 1977), affd. mem., 573 F.2d 1301 (3d Cir. 1978); Computer Statistics, Inc. v. Blair, 418 F. Supp. 1339, 1352 (S.D. Tex. 1976); Dorfman v. First Boston Corp., 70 F.R.D. 366, 373-74 (E.D. Pa. 1976). Contra CTS Corp. v. Electro Materials Corp., 476 F. Supp. 144, 145 (S.D.N.Y. 1979); Scheriff v. Beck, 452 F. Supp. 1254, 1261 (D. Colo. 1978).

64 See Pacific Coast Agricultural Export Ass'n v. Sunkist Growers, Inc., 526 F.2d 1196, 1210 n.19 (9th Cir. 1975), cert. denied, 425 U.S. 959 (1976) (" most attorneys engaged in the antitrust practice use ... legal assistants . . . [to perform] much of the work heretofore performed by relatively inexperienced lawyers" ") (quoting the district court); Chapman v. Pacific Tel. \& Tel. Co., 456 F. Supp. 77, 83 (N.D. Cal. 1978) ("The work performed by them is work of a kind necessary to the prosecution of the litigation which will, or ought to be, performed, if not by them, by attorneys"); Computer Statistics, Inc. v. Blair, 418 F. Supp. 1339, 1352 (S.D. Tex. 1976) ("paralegals perform valuable legal services previously performed by young attorneys"); Merchandise Nat'l Bank v. Scanlon, 86 Ill. App. 3d 719, 726-27, 408 N.E.2d 248, 254-55 (1980) (certified senior law student separately recompensated for performing tasks that otherwise would have been performed by an attorney); cf. Postow v. Oriental Bldg. Ass'n, 455 F. Supp. 781, 788 (D.D.C. 1978) (law clerks not compensated because it could not be determined whether work otherwise would have been performed by an attorney). 
services, are often valued at the market rate, allowing for a margin of profit. ${ }^{\text {b5 }}$

In a second line of cases, courts have evaluated requests for attorneys' fees from pro se plaintiffs. These cases support the proposition that courts have taken a functional approach in defining "attorneys." Their holdings do not fall into a well-defined pattern; fees may be awarded to a pro se litigant in one court ${ }^{66}$ and be denied in another ${ }^{67}$ Regardless of result, however, the reasons usually employed by the courts to reach their decisions are instructive.

An award of fees to a pro se representative presents persuasive evidence that the formal approach has been rejected. For example, in Holley $v$. Acree, ${ }^{68}$ the court granted a nonlawyer's request for attorneys' fees and observed that when persons choose to represent themselves in legal proceedings "they are in every sense functioning as attorneys: they do research, file pleadings, and advocate their cause." 69 Although such language undeniably reflects a broad view of "attorney" for the purposes of fee awards, support for that view may be found even in cases denying attorneys' fees.

Significantly, the decisions denying fee awards to pro se litigants often do not turn merely on the lay status of the party. Instead, courts have attempted to determine whether the policies underlying the attorneys' fees provisions would be furthered by awarding fees even in the absence of a traditional attorney-client relationship. ${ }^{70}$ Indeed, some courts have used the same reasoning

65 See, e.g., Bolden v. Pennsylvania State Police, 491 F. Supp. 958, 965 (E.D. Pa. 1980) ( $\$ 35$ per hour for student intern); Wehr v. Burroughs Corp., 477 F. Supp. 1012, 1017 (E.D. Pa. 1979) ( $\$ 27.50$ per hour for paralegal); Pennsylvania v. O'Neill, 431 F. Supp. 700, 711 (E.D. Pa. 1977), aff'd. mem., 573 F.2d 1301 (3d Cir. 1978) ( $\$ 20.10$ per hour for summer associate); Computer Statistics, Inc. v. Blair, 418 F. Supp. 1339, 1352 (S.D. Tex. 1976) ( $\$ 20.00$ per hour for paralegals). But see Chapman v. Pacific Tel. \& Tel. Co., 456 F. Supp. 77, 83 (N.D. Cal. 1978) (fees for paralegal-law clerk services limited to actual or reasonable cost, whichever is lower).

66 Cuneo v. Rumsfeld, 553 F.2d 1360 (D.C. Cir. 1977); Jones v. United States Secret Service, 81 F.R.D. 700 (D.D.C. 1979); Holly v. Acree, 72 F.R.D. 115 (D.D.C. 1976), aff'd without opinion sub nom. Holly v. Chasen, 569 F.2d 160 (D.C. Cir. 1977).

67 White v. Arlen Realty and Dev. Corp., 614 F.2d 387 (4th Cir.), cert. denied, 447 U.S. 923 (1980); Hannon v. Security Nat'l Bank, 537 F.2d 327 (9th Cir. 1976); Barrett v. United States Customs Serv., 482 F. Supp. 779 (E.D. La. 1980).

68 Holly v. Acree, 72 F.R.D. 115 (D.D.C. 1976), aff d without opinion sub nom. Holly v. Chasen, 569 F.2d 160 (D.C. Cir. 1977).

69 Id. 116.

70 See, e.g., Hannon v. Security Nat'l Bank, 537 F.2d 327 (9th Cir. 1976), in which the court interpreted the legislative history of the Truth in Lending Act, 15 U.S.C. $\$ 1601-1667 \mathrm{e}$ (1976), as precluding attorneys' fees for pro se litigants. 
to deny fee awards to pro se plaintiffs who themselves were attorneys. ${ }^{71}$

Although neither line of decisions reviewed here provides conclusive support for fee awards recognizing student lawyering, both suggest that the concept of "attorney" relevant to the awards mechanism is a functional one. Were fee awards as a matter of definition available only to licensed attorneys, the decisions awarding fees to lay persons would be plainly incorrect; moreover, the reasoning in decisions denying fee awards would be superfluous. Recognition that the student-client relationship is, in most respects, functionally indistinguishable from the attorney-client relationship ${ }^{72}$ leads to the conclusion that court awarded fees based on student lawyering would be consistent with prior interpretations of the fee awards provisions. Indeed, Congress recently recognized this functional concept in the Equal Access to Justice Act, which authorizes attorneys' fees awards to nonlawyer "agents" when an administrative agency permits such "agents" to appear before it. ${ }^{73}$

\section{Should Courts Award Attorneys' Fees to LAW SCHOOL CLINICS?}

In Jordan v. United States Department of Justice, ${ }^{74}$ the plaintiff, who had been denied access to certain documents by the Department of Justice, prevailed on the merits in his suit under the Freedom of Information Act. ${ }^{75}$ He requested $\$ 17,000$ in attorneys' fees, including $\$ 2,000$ recognizing the work of law students at one of Georgetown University Law Center's legal clinics. ${ }^{70}$ Judge Aubrey Robinson denied the request for attorneys' fees, terming

Cf. Grooms v. Snyder, 474 F. Supp. 380, 384 (N.D. Ind. 1979) (lay advocate was not the "competent counsel" the Fees Act attempts to encourage).

71 For example, in White v. Arlen Realty \& Dev. Corp., 614 F.2d 387 (4th Cir. 1980), the plaintiff, an attorney appearing pro se, prevailed in twelve counts under the Truth in Lending Act, 15 U.S.C. $\$ 1601-1667 \mathrm{e}$ (1976). The court - denied attorneys' fees, finding that the goal of the statute's attorneys' fees provision, 15 U.S.C. $\$ 1640$ (a)(3) (1976), was to provide both legal expertise and a detached and objective perspective. Although the plaintiff had sufficient legal - expertise to win the case, the court reasoned that an award of attorneys' fees would not further the goal of providing detached and objective counselors.

72 See supra notes 15-33 and accompanying text.

${ }^{73}$ Equal Access to Justice Act, Pub. L. No. 96-481, $\$ 203,94$ Stat. 2321, 2325 (to be codified in 5 U.S.C. $\$ 504$ ); H.R. RER. No. 1418, 96th Cong., 2d Sess. 14 (1980).

7489 F.R.D. 537 (D.D.C. 1981).

765 U.S.C. $\$ 552$ ( $1976 \&$ Supp. III 1979).

7689 F.R.D. at 541. 
the record-keeping "abysmal" 77 and the billing rates "excessive." 78 . Moreover, he considered the request for fees for student services "unprecedented and unsupportable" 79 because "law clerks are not attorneys" ${ }^{80}$ and "were free to the Plaintiff in this case." 81

In North Slope Borough v. Andrus, 82 Judge Robinson extended his explanation why it is inappropriate to award attorneys' fees to law school clinics. Plaintiffs, represented by the Center for Law and Social Policy, included a claim for $\$ 7,050$ for the services of law students in their request for attorneys' fees. ${ }^{83}$ The court granted the request, reasoning that the Center incurs substantial costs in maintaining a student intern program and that these costs would properly be billed to a client. ${ }^{84}$ Thus, they are compensable. In Jordan, by contrast:

Plaintiff's attorney was a law school clinical program whose primary function is to educate law students. The law school and the students were engaged in a quid pro quo; the students paid tuition to the "attorney" in return for course credit and legal training. Through their contract with the law school, the students themselves paid the "costs" associated with their contribution to the litigation. Thus, the students were provided to Plaintiff's "attorney" (and thus the Plaintiff) cost-free. Since the "attorney" could not properly bill Plaintiff for the cost-free services of the law students, the costs would not be properly billed to his adversary. ${ }^{85}$

Judge Robinson articulates several objections to awarding attorneys' fees to law school clinics: that their students are not lawyers and are not paid, that they do not charge clients for their services, and that receiving fee awards is incompatible with their educational nature. This analysis, however, uses a formal rather than a functional definition of "attorney" and focuses primarily on the financial arangements between attorney and client; it ignores

77 Id.

78 Id.

79 Id. 540.

80 Id. 541.

81 Id.

82515 F. Supp. 961 (D.D.C. 1981).

83515 F. Supp. at 971 . The requests were filed under the attorneys' fees provisions of the Endangered Species Act, 16 U.S.C. $\$ 1540(\mathrm{~g})(4)(1976)$, and the Outer Continental Shelf Lands Act, 43 U.S.C. $\$ 1349$ (b)(2) (Supp. III 1970).

84515 F. Supp. at 871.

85 Id. (citation omitted). 
-other aspects of the attorney-client relationship that may make fee awards for student lawyers appropriate. Moreover, it fails to recognize that attorneys' fees mechanisms are addressed not only to the prevailing plaintiff but also to the motives and behavior of the losing party. ${ }^{80}$

The validity of Judge Robinson's objections may be assessed by comparing the features of a university legal clinic with those of a legal services office and those of a private law firm. The law firm bills clients and pays salaries to attorneys and student clerks. The firm may be awarded attorneys' fees that include compensation for the paid student clerks' work. ${ }^{87}$

A legal services office has salaried attorneys, but it does not bill clients. Nevertheless, the office ${ }^{88}$ is eligible for fee awards. ${ }^{89}$ Courts have recognized that a contrary rule would thwart the purposes of statutory attorneys' fees provisions. ${ }^{90}$

86 See supra notes 34-52 and accompanying text; infra notes 94-97 and accompanying text.

87 See Pennsylvania v. O'Neill, 431 F. Supp. 700, 711 (E.D. Pa. 1977); Dorfman v. First Boston Corp., 70 F.R.D. 366, 374 -(E.D. Pa. 1976). Contra CTS Corp. v. Electro Materials Corp., 476 F. Supp. 144, 145 (S.D.N.Y. 1979) (denying fees to compensate for law student services rendered to corporation counsel).

88 The awards provisions generally call for awards to the prevailing party. If that party, however, has no obligation to pay his or her attorney, courts have awarded the fees directly to the attorney. In doing so, the courts apparently have not been troubled by this deviation from statutory language. Those courts that have addressed the question have concluded that their equity powers allow such deviation to prevent a "windfall" to the prevailing party. See Rodriguez v. Taylor, 569 F.2d 123I, 1245 (3d Cir. 1977), cert. denied, 436 U.S. 913 (1978); Hairston v. R \& R Apartments, 510 F.2d 1090, 1093 (7th Cir. 1975).

89 The courts generally have refused to condition fee awards on the existence of the client's contractual obligation to pay an attorney for his or her services. See, e.g., Rodriguez v. Taylor, 569 F.2d 1231, 1245 (3d Cir. 1977), cert. denied, 436 U.S. 913 (1978); Torres v. Sachs, 538 F.2d 10, 13 (2d Cir. 1976); Brandenburger v. Thompson, 494 F.2d 885, 889 (9th Cir. 1974) (cases holding that the presence of an attorney-client relationship is itself sufficient). Awards of fees to public interest firms or to other legal assistance offices, as well as to pro bono representatives from the private bar, therefore, have been upheld. See, e.g., Copeland v. Marshall, 641 F.2d 880, 900 (D.C. Cir. 1980); Dennis v. Chang, 611 F.2d 1302, 1304-05 (9th Cir. 1980); Lund v. Affleck, 587 F.2d 75, 76 (Ist Cir. 1978); Hairston v. R \& R Apartments, 510 F.2d 1090, 1092 (7th Cir. 1975); Incarcerated Men v. Fair, 507 F.2d 281, 286 (6th Cir. 1974). Commentators have applauded this line of decisions. See, e.g., McLaughlin, supra note 34; Nussbaum, Attorney's Fees in Public Interest Litigation, 48 N.Y.U. L. Rev. 301 (1973); Comment, supra note 49; Note, Awards of Attorney's Fees to Legal Aid Offices, 87 Hanv. L. Rev. 411 (1973).

90 The award of fees to legal aid offices and other groups furnishing pro bono publico representation promotes the enforcement of the underlying statutes as much as an award to privately retained counsel. Legal services organizations often must ration their limited financial and manpower resources. Allowing them to recover fees enhances their capabilities to assist in the enforcement of congressionally favored individual rights.

.Rodriguez, 569 F.2d at 1245 . 
Legal clinics neither charge their clients nor pay their student attorneys. As the North Slope decision indicates, however, a fee award may be based on the work of student volunteers. In that case, the court found that the Center and its clients bore the costs of operating the student program. Universities, however, also bear the costs associated with clinical programs. Clinics are simply more expensive to operate than large lecture classes. ${ }^{91}$

Thus, Judge Robinson's objections may be reduced to one: fee awards are incompatible with the educational mission of legal clinics. The validity of this objection, however, might be better assessed by the educators at the universities, who presumably are in the best position to decide whether litigating for attorneys' fees furthers the goals of clinical education. They may believe that such litigation would expose students to an important area of actual practice and teach them the value of carefully recording the time spent on each matter.

More importantly, if a law school clinic may not be awarded attorneys' fees for student lawyering, the policies of the attorneys' fees mechanisms will suffer and the rights of the clinic's clients may be abridged. For example, the bad faith exception is designed to punish the offending party and to deter similar conduct in the future.92 Were bad faith awards generally unavailable to clinical programs, legal adversaries of individuals represented by law students would have license to harrass their opponents with impunity, with consequent harm both to the client and to the integrity of the legal system. Accordingly, a general policy that clinical programs should not receive attorneys' fees under the bad faith exception not only would fail to advance the goals of the doctrine but also would implicitly sanction the very conduct it was designed to eliminate.

Equally persuasive reasons exist to justify awards under statutory provisions designed to encourage vindication of substantive rights of legislative policies, such as the Fees Act. ${ }^{93}$ A purpose of these provisions is to promote the ability and willingness of the bar to represent indigent persons. ${ }^{94}$ The prospect of a fee award

91 See supra note 11.

92 See supra notes $37-41$ and accompanying text.

93 42 U.S.C. \$1988 (1976).

94 See Johnson v. Georgia Highway Express, Inc., 488 F.2d 714, 716 (5th Cir. 1974); Grooms v. Snyder, 474 F. Supp. 380, 384 (N.D. Ind. 1979); Alsager v. District Court, 447 F. Supp. 572, 577 (S.D. Iowa 1977). Generally, law school clinics, like legal aid organizations, represent clients in the absence of any fee arrangement. 
may not influence the decision whether to represent a particular client; the granting of an award, however, certainly enhances an organization's ability to provide similar services to others. ${ }^{95}$

This reasoning is equally sound when applied to clinical programs. The resources of these programs and their universities are not infinite; indeed, imposing budgetary restrictions on clinical programs may be an ever-present temptation. Attorneys' fees awards to law school clinics, therefore, could contribute to their continuing viability. Such awards also would be consistent with other policies promoted by the fee provisions-for example, deterrence of socially undesirable conduct. As the court noted in Rodriguez $v$. Taylor, "assessing fees against defendants in all circumstances may deter wrongdoing in the first place." 98 Finally, when the remedy sought is nonpecuniary, such as injunctive relief, the offending party often has little to lose by waging a protracted battle against an indigent plaintiff. The possibility of a fee award at the conclusion of the litigation may be a clinic's most powerful instrument in settlement negotiations. ${ }^{97}$ Without consistent application of the awards provisions in all circumstances, clients of clinical programs are deprived of the bargaining power possessed by persons who have secured other forms of representation. Not only is this manifestly unfair to the clinic's client, but its practical result also is an unjustifiable windfall to the defendant. ${ }^{98}$

\section{Conclusion}

Provisions and doctrines allowing courts to award attorneys' fees are designed to further a number of different interests. Recognizing these interests, the courts have adopted a functional interpretation of attorneys' services and have refused to condition fee awards on the existence of a particular form of attorney-client

95 See Oldham v. Ehrlich, 617 F.2d 163, 168 (8th Cir. 1980); Rodriguez v. Taylor, 569 F.2d 1231, 1245 (3d Cir. 1977), cert. denied, 436 U.S. 913 (1978); Torres v. Sachs, 538 F.2d 10, 13 (2d Cir. 1976).

${ }^{96}$ Rodriguez, 569 F.2d at 1245; see also Oldham v. Ehrlich, 617 F.2d 163, 168-69 (8th Cir. 1980) (statute's purpose of awarding attorneys' fees to deter wrongdoing is furthered by awarding fees to legal services attorneys); Page v. Preisser, 468 F. Supp. 399, 403 (S.D. Iowa 1979) (disparate payments to public interest and private attorneys might detract from deterrent effect of fee shifting).

97 Dennis v. Chang, 611 F.2d 1302, 1307 (9th Cir. 1980); of. Alsager v. District Court, 447 F. Supp. 572, 578 (S.D. Iowa 1977) (counsel's ability to induce settlement not impaired because the fees actually awarded not substantially different from those that would have been awarded to private counsel).

98 Oldham v. Ehrlich, 617 F.2d 163, 168-69 (8th Cir. 1980); Palmigiano v. Garrahy, 616 F.2d 598, 602 (1st Cir. 1980). 
relationship. Law students in clinical programs often provide the same services to their clients that an attorney would provide; their work advances the same interests and values as the work of licensed attorneys. There is no justification for differentiating between these two groups in a way that thwarts the avowed purposes of the awards provisions and the interests of the students' clients, simply because the students are students. 